2. Dean, M. F., Muir, H., Benson, P. F., Button, L. R., Batchelor, J. R. and Bewick, $\mathbf{M}$ : Increased breakdown of glycosaminoglycans and appearance of corrective enzyme after skin transplants in Hunter syndrome. Nature 257: 609 (1975).

3. Dean, M. F., Stevens, R. L., Muir, H., Benson, P. F., Button, L. R., Anderson, L. R., Boylston, A. and Mowbray, J.: Enzyme replacement therapy by fibroblast transplantation. J. Clin. Invest. 63: 138 (1979).

4. Moser, H. W., O'Brien, J. S., Atkins, L., Fuller, T. C., Keiman, A., Janowska, S., Russel, P. F., Bartsocas, C. S., Cosimi, B. and Dulaney, J. T.: Infusion of normal HLA-identical leukocytes in Sanfilippo disease type B. Arch. Neurol.,
31: 329 (1974).

5. O'Brien, J. S., Miller, A. L., Loverde, A. W. and Veath, M. L.: Sanfilippo disease type B: enzyme replacement and metabolic correction in cultured fibroblasts. Science, 181: 753 (1973).

6. von Figura, K., Lögering, M., Mersmann, G. and Kresse, H.: Sanfilippo B disease: serum assays for detection of homozygous and heterozygous individuals. J. Pediatr., 83: 607 (1973).

7. We are indebted to Mrs. S. Heuertz for her skillful technical assistance.

\title{
Letter to the Editor: Effectiveness of HLA- Compatible Fibroblasts for Enzyme Replacement Therapy in the Mucopolysaccharidoses
}

\author{
M. F. DEAN, HELEN MUIR, P. F. BENSON, AND L. R. BUTTON \\ Division of Biochemistry, Kennedy Institute, London, U.K. and Pediatric Research Unit, Guy's Hospital Tower, \\ London, U.K.
}

We transplanted HLA compatible fibroblasts into several patients with different types of mucopolysaccharidoses in an attempt to provide a long lasting source of lysosomal enzymes for replacement therapy (Dean et al. 3, 4, 5).

In one group of patients deficient in $\alpha$-L-idurono-2-sulphate sulphatase (Hunter syndrome) and another group deficient in glucosamine-N-sulphate sulphatase (Sanfilippo A syndrome), we observed a number of biochemical changes subsequent to a single transplant. These changes included increased excretion of accumulated glycosaminoglycan storage products, a reduction in the relative proportions of higher molecular weight oligosaccharides and a marked reduction in their degree of oversulphation. Coupled with these changes we observed an increase in the activity of previously deficient lysosomal enzymes measured as excreted "corrective factors". All the above effects persisted for many months.

However, we were unable to demonstrate any consistent changes following a similar transplant in a group of two patients with $\alpha$-L-iduronidase deficiency (Hurler syndrome), Dean et al. unpublished data. Neither were we able to detect a consistent increase in glucosamine- $\mathrm{N}$-sulphatase activity in our patients with Sanfilippo disease when $\left[{ }^{35} \mathrm{~S}\right]$-labeled heparin was used as a substrate for direct enzyme assay. Leucocytes and serum samples taken from two of our Hunter patients more than a year after transplant did, however, have slightly higher levels of $\alpha$-L-idurono2-sulphate sulphatase than age matched control untreated patients when tested against a $\left[{ }^{3} \mathrm{H}\right]$-labeled disulphated disaccharide substrate.

All our patients exhibited severe primary and secondary symptoms of their diseases prior to transplant and we did not detect sustained clinical improvements in any of them following treatment.

The intracellular half lives of most lysosomal enzymes are very short, $\alpha$-L-idurono-2-sulphate sulphatase and glucosamine-N-sulphatase for example each being only 2 days after uptake into fibroblasts [Cantz et al., (2), Kresse and Neufeld (7)]. The long lasting effects we observed following single transplants of fibroblasts could only therefore be explained if at least some of the fibroblasts had survived and continued to secrete lysosomal enzymes. The fact that a relatively small number of transplanted cells induced such large changes in excreted enzymes and GAG led us to speculate that perhaps the transplanted cells may have divided in vivo. We do not however have any direct evidence that either supposition is correct.
Transplanted fibroblasts have produced measurable effects in other patients; Gibbs et al. (6) for example noted changes in excreted GAG in Hunter patients. On the other hand Munnich et al. (8) could detect no changes when they transplanted fibroblasts into a patient with Sanfilippo B syndrome. We do not have enough information to explain this variability in results.

We ourselves have no experience with Sanfilippo B patients. Since this syndrome results from a glycosidase deficiency rather than absence of a sulphatase, however, it may be less amenable to replacement therapy than sulphatase deficiencies such as Hunter and Sanfilippo A diseases. Furthermore, since each lysosomal enzyme deficiency other than those within the same pedigree is attributable to a separate gene mutation, there may be considerable variation in responsiveness even within a group of patients with the same inborn error. Other discrepancies may result from differences in experimental protocol. Lack of immunosuppression before transplant for example may explain the failure of graft survival. The method employed for enzyme assay is also important. Detection of previously deficient enzymes by correction of $\left[{ }^{35} \mathrm{~S}\right]$-sulphate incorporation has been shown to be 14 times more sensitive than direct enzyme assay in the case of $\beta$-glucuronidase [Brot et al. (1)]. Very low amounts of lysosomal enzymes, which may be present in serum or urine following transplants, may thus be undetectable by direct assay but demonstrable indirectly by their ability to reduce $\left[{ }^{35} \mathrm{~S}\right]$-sulphate incorporation in patients' cells. Finally, the failure to identify donor cells at the site of transplantation or to demonstrate $\mathrm{N}$-acetyl- $\alpha$-glucosaminidase activity there reported by Munnich et al. (8) may be explained by the fact that their biopsy was limited to full-thickness skin. Donor fibroblasts transplanted into deeper subcutaneous sites may not therefore have been revealed.

\section{REFERENCES AND NOTES}

1. Brot, E. F., Glaser, J. H., Roozen, K. J. and Sly, W. S.: In vitro correction of deficient human fibroblasts by $\beta$-glucuronidase from different human sources. Biochem. Biophys. Res. Commun., 57: 1 (1974).

2. Cantz, M., Chrambach, A., Bach, G. and Neufeld, E. F.: The Hunter corrective factor: purification and preliminary characterisation. J. Biol. Chem.. 247: 5456 (1972).

3. Dean, M. F., Muir, H., Benson, P. and Button, L. R.: Enzyme replacement therapy in the Mucopolysaccharidoses by fibroblast transplantation. In: Birth Defects: Original Article Series, Vol. XVI, No. l. (Ed.) Desnick, R.J. pp. 445 456 (R.J. Liss Inc., New York, NY 1980).

4. Dean, M. F., Muir, H., Benson, P. F. and Button, L. R.: Enzyme replacement therapy by transplantation of HLA-compatible fibroblasts in Sanfilippo A syndrome. Pediatr. Res., 15: 959 (1981). 
5. Dean, M. F., Stevens, R. L., Muir, H., Benson, P. F., Button, L. R., Anderson, R L., Boylston, A. and Mowbray, J.: Enzyme replacement therapy by fibroblast transplantation: long-term biochemical study in three cases of Hunter's disease. J. Clin. Invest., 63: 138 (1979).

6. Gibbs, D. A., Spellacy, E., Roberts, A. E. and Watts, R. W. E.: The treatment of lysosomal storage diseases by fibroblast transplantation: some preliminary observations. In: Birth Defects: Original Article Series, Vol. XVI, No. 1. (Ed.)
Desnick, R.J. pp. 457-474 (A.R. Liss Inc., New York, NY 1980).

7. Kresse, H. and Neufeld, E. F.: The Sanfilippo A corrective factor: purification and mode of action. J. Biol. Chem.. 247: 2164 (1972).

8. Munnich, A., Sandubray, J. M., Hors, M. C., Poenaru, L., Ogier, H., Strecker. G., Aicardi, J., Frezal, J. and Maroteaux, P.: Enzyme replacement therapy by transplantation of HLA-compatible fibroblasts in Sanfilippo syndrome: Another trial. Pediatr. Res., in press.

\section{ANNOUNCEMENT}

The annual meeting of the American Society of Pediatric Nephrology will be held at the Sheraton Washington Hotel in Washington, DC on Thursday evening, May 13, and Friday morning, May 14, 1982. The symposium is entitled, "The Role of the Kidney in Calcium and Phosphate Homeostasis." For further information, please contact Dr. Russell Chesney, Secretary-Treasurer, American Society of Pediatric Nephrology, University of Wisconsin Clinical Sciences Center (H4/452), 600 Highland Avenue, Madison, Wisconsin 53792.

World Congress on Mental Retardation of the International Association for the Scientific Study of Mental Retardation, Toronto, Canada, August 22-26, 1982.

To receive full information on program, study tours, travel, presentation of papers, etc., write IASSMD, Kinsmen Building, York University Campus, 4700 Keele Street, Downsview, Ontario, Canada M3J IP3. 